\title{
A study of correlations and path analyses of some traits in sunflower parental lines
}

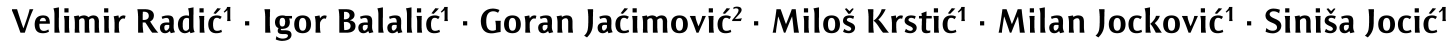 \\ 1 Institute of Field and Vegetable Crops, Novi Sad, Serbia \\ 2 University of Novi Sad, Faculty of Agriculture, Novi Sad, Serbia
}

\begin{abstract}
Summary: The trial in this study was carried out in field conditions throughout three years from plots where seed production of sunflower parental lines was established. Eight genotypes were examined; namely RHA-UK, RHA-ST59, RHA-SES-IMI, RHA-SNRF, RHA-E-ANN-65, RHA-RU-3, RHA-CDN, and RHA-N-M-1. All the examined genotypes are parental components of the best sunflower hybrids developed by the Institute of Field and Vegetable Crops, Novi Sad, Serbia. Relationships between seed yield and eight different traits in sunflower were studied - oil and protein content, seed germination, 1000-seed weight, head diameter, number of branches and leaves and plant height. The same analyses were carried out for comparison of oil content. A highly significant positive correlation was determined between plant height and number of branches; plant height and the number of leaves; plant height and head diameter; plant height and seed yield; number of branches and yield; the number of leaves and yield; head diameter and seed yield; number of leaves and number of branches; number of leaves and head diameter and between seed germination and oil content. Path analysis indicated highest significant direct effect of plant height on yield $\left(0.439^{* *}\right)$. The number of branches had a significant positive direct effect on yield $\left(0.260^{*}\right)$. In the study of indirect effects on yield, thirteen significant effects were determined. The study of direct effects on oil content showed that the plant height and number of leaves diameter had high significant effects $\left(0.800^{* *}\right.$ and $\left.-0.847^{* *}\right)$. The existence of indirect significant effects on oil content was determined in nine cases.

Key words: correlation analysis, path analysis, sunflower, yield components
\end{abstract}

\section{Introduction}

The accomplishment of breeding programs mainly depends on the variation present for yield and yield components as well as the nature of the hereditary material (Nehru \& Manjunath, 2003). The extent of the relationship between phenological, seed yield and oil traits would ultimately enhance their selection efficiency for the above traits (Riaz et al., 2019). Yield is a

\section{Corresponding author:}

velimir.radic@ifvens.ns.ac.rs

Acknowledgements:

This research is part of the project 31025: Development of new varieties and production technology improvement of oil crops for different purposes, financed by the Ministry of Education, Science and Technological Development, Republic of Serbia.

\section{Cite this article:}

Radić V., Balalić I., Jaćimović G., Krstić M., Jocković M., Jocić S. (2021). A study of correlations and path analyses of some traits in sunflower parental lines. Ratar. Pourt., 58 (1), 7-13.

\section{(c) (1)}

Copyright (C) The Author(s) 2021 complex character and is a function of several component characters and their interactions with the environment (Chikkadevaiah \& Nandini, 2002). Yield is influenced by a set of other characters known as yield components which are related among themselves and with yield either favourably or unfavourably (Pandya et al., 2015). These authors also notice, in most crops, the associations among yield components are reported to be undesirable thereby hindering the rapid progress that could be made. Hence, it would be necessary to know what kind of relationship exists among and between morphological and yield components and whether a given relationship is a true one. The selection of characters that have high heritability and a positive association with yield is an important requirement for improving yields through breeding programs (Sincik \& Goksoy, 2014). Therefore, indirect selection through associated component traits is possible to improve the seed yield (Darvishzadeh et al., 2011). In breeding for yield improvement, it is important to find morphological and physiological characteristics that are easily measured and at the same time demonstrate a causal relationship with seed yield and therefore can be 
used as selection criteria (Chambo et al., 2017). According to Supriya et al. (2017), the seed yield is a function of genetic potential of the variety, external conditions in which the crop is grown, applied technology and the interaction of all these factors. The most important criteria for introducing new hybrids into production are: protein and seed yield, plant height, head diameter, seed protein content, seed oil content, number of seeds per head, 1000 seed weight, seed size etc. (Pekcan et al., 2015; Hladni et al., 2016). Radić et al. (2013) concluded that further research should be aimed at observation of the relationship between certain characters of seed quality, with the intention of obtaining high quality sunflower seed. The study on the relationships between yield and yield related traits will improve the efficiency of breeding program by determining appropriate selection criteria (Darvishzadeh et al., 2011).

Presence or absence of correlations can contribute to the right choice of examined traits so as to enhance the efficiency of some selection criteria. The focus should be placed on traits that have a very strong positive correlation on seed yield (Hladni et al., 2011). Simple correlation analysis cannot give details about relationship of yield and yield related traits so that path coefficient analysis is used. It is a tool that splits the correlation coefficient into its direct and indirect effects (Tahir et al., 2019). Path coefficient analysis has an advantage over estimation of simple correlation coefficients because it allows partitioning of the correlation coefficient into its components (Supriya et al., 2017). According to Yasin \& Singh (2010), path coefficient analysis provides an excellent tool as it can measure the direct and indirect effects of interrelated components of a complex trait like yield.

In the present study, an attempt was made to investigate correlation coefficient of several traits with seed yield and oil content of sunflower and determinate of direct and indirect effects of the studied traits by path analysis in sunflower genotypes in order to identify research priorities in sunflower breeding.

\section{Material and Methods}

Experiment was carried out in field conditions throughout three years from plots where seed production of sunflower parental lines was established. Eight genotypes were examined; namely RHA-UK, RHA-ST-59, RHA-SES-IMI, RHA-SNRF, RHA-EANN-65, RHA-RU-3, RHA-CDN, and RHA-N-M-1. All the examined genotypes are parental components of the best sunflower hybrids developed by the Institute of Field and Vegetable Crops, Novi Sad, Serbia.

The following parameters were studied:

Plant height, number of leaves, number of branches and head diameter - 10 plants per replication were picked manually, from different locations on the plot.

Seed yield - upon maturity, 10 plants were picked manually, from different locations on the plot, and seed yield per plant was determined. Obtained seed yield per plant was redetermined in $\mathrm{kg} \mathrm{ha}^{-1}$ with $9 \%$ of moisture. Upon seed drying, specimens were purified and cleaned. Seed for determining the remaining observed parameters were picked from the given specimens:

Seed germination - Standard method of testing authorised by Handbook of Vigour Test Methods (ISTA, 2014) was used. Examination of seed germination was repeated 4 times. Each time 100 seeds were used. Germination was determined after 10 days. Only naturally formed germinated seeds were used for determination of this parameter. Germination was expressed in relative values.

1000-seed weight - Examination of 1000-seed weight was repeated 4 times. Each time 100 seeds were used. The obtained value was applied to 1000 -seed weight and was specified in grams.

Oil content - Determined by the classical method by Ruškovski and expressed in relative value.

Protein content - Determined by standard Kiedahl method using VAP-50-Gerhardt apparatus. This parameter is also expressed in relative value.

Simple correlation coefficient and path coefficient analysis for examined characters were carried out using STATISTICA 12.0 software (2009).

\section{Results and discussion}

A successful breeding program for standard sunflower hybrids requires knowledge of a well-defined association between agronomical and technological characters.

\section{Correlation coefficient}

By calculation of simple correlation coefficients, a highly significant positive correlation was found between plant height and number of branches; plant height and the number of leaves; plant height and head diameter and between plant height and seed yield (Table 1). Also, highly significant positive correlation was found between the number of branches and seed yield; the number of leaves and seed yield; head diameter and seed yield; number of leaves and number of branches; number of leaves and head diameter and between seed germination and oil content.

Previous studies by Shankar et al. (2006), Yasin \& Singh (2010), Kholghi et al. (2011) and Radić et al. (2013) reported similar findings. These authors concluded that seed yield is positively correlated with the 1000-seed weight, head diameter and plant height. Sincik \& Goksoy (2014) determined significant and positive correlation coefficients between the seed yields and the plant heights, head diameters, and 1000-seed weights. Hassan et al. (2013) and Jalil et al. (2014) reported that seed yield was positively and significantly correlated with head diameter, number of achenes per head, head weight, 100-seed weight and oil contents. According to Pandya et al. (2015), plant height showed significant and positive correlations with head diameter, 
Table 1. Simple correlation coefficients between different seed characters in sunflower

\begin{tabular}{ccccccccc}
\hline Characters & NB & NL & HD & SG & SW & PC & OC & Y \\
\hline PH & $0.539^{* *}$ & $0.665^{* *}$ & $0.702^{* *}$ & -0.146 & -0.151 & 0.001 & 0.171 & $0.623^{* *}$ \\
NB & & $0.692^{* *}$ & $0.232^{*}$ & $-0.252^{*}$ & -0.088 & 0.064 & -0.002 & $0.552^{* *}$ \\
NL & & & $0.349^{* *}$ & -0.161 & -0.213 & -0.140 & -0.219 & $0.534^{* *}$ \\
HD & & & & $-0.324^{* *}$ & 0.050 & -0.163 & 0.040 & $0.446^{* *}$ \\
SG & & & & & $-0.333^{* *}$ & -0.073 & $0.309^{* *}$ & $-0.321^{* *}$ \\
SW & & & & & & -0.076 & 0.041 & -0.164 \\
PC & & & & & & -0.120 & -0.022 \\
OC & & & & & & & & -0.003 \\
\hline
\end{tabular}

PH - plant height; NB - number of branches; NL - number of leaves; HD - head diameter; SG - seed germination; SW - 1000 seed weight; PC - protein content; $\mathrm{OC}$ - oil content and $\mathrm{Y}$ - yield

number of seeds per capitula and number of filled seeds per capitula. Also, they found highly significant positive correlation between seed yield and head diameter, plant height, and 100 seed weight. On the other side, Manivannan et al. (2008) reported that the correlation between seed yield and the head diameter was negative and not significant. A highly significant negative correlation was determined between head diameter and seed germination; seed germination and 1000-seed weight and between seed yield and seed germination (Table 1). Mrda et al. (2011) stated that seed germination plays a direct role in determining plant number per hectare, which is one of three main yield components. In his study, Radić (2008) concluded that seed germination depends on several factors. These factors are connected with climate, genotype (for example days of maturity for restorer lines), year of production (dry or rainy season), the location of production, plant density etc. Significant positive correlation was determined between the number of branches and head diameter while significant but negative correlation was determined between the number of branches and seed germination. Comparing all other observed correlations, we determined positive and negative but not significant values (Table 1). Results of our study are not in agreement with Balalić et al. (2012) who reported a significant correlation between seed yield, oil yield and oil content, while Hladni et al. (2016) reported a significant correlation between protein content and yield in confectionary sunflower. Chambo et al. (2017) did not find a correlation between seed yield and 1000-seed weight, but they found negative correlations between 1000-seed weight and oil content. Significant and positive correlation between seed yield and seed oil content communicated by Shankar et al. (2006), Farhatullah \& Khalil (2006), Anandhan et al. (2010) and Radić et al. (2013) and they are in disagreement with our results. According to Pandya et al. (2015), oil content showed negative non-significant correlation with days to maturity, stem diameter, number of leaves per plant, plant height, and 100 seed weight. Yankov \& Tahsin (2015) found negative but not significant correlation between oil content and head diameter while positive correlation was found between oil content and plant height. These authors concluded that seed yield could be increased by selection of plant height, stem diameter and number of seeds, because they had a high positive correlation with seed yield and they also showed high heritability. Oil content was positively associated with duration of the reproductive phase, head diameter and seed volume weight, whereas the association between hull content and oil content was found to be highly significant and negative (Singh et al., 2018). Kaya et al. (2008) found highly significant and positive correlation between yield and 1000-seed weight. They also found significant correlation between plant height and head diameter in comparison with yield, but only in a dry period. Radić et al. (2013) determined negative, but not significant correlation between 1000-seed weight and seed germination. Radić (2008) concluded that, in some years, smaller and medium seed can have better germination then large seed. Chambo et al. (2017) suggested, based on their studies that more research is required to investigate the relationship between certain parameters associated with the physiological quality of seeds, as well as those associated with seed yield components, to obtain high quality sunflower seeds.

A negative not significant correlation was determined between 1000-seed weight and yield (Table 1). These results are in agreement with Hladni et al. (2015), but in disagreement with Radić et al. (2013) and Gorgieva et al. (2015). Miklič et al. (2012) reported that 1000-seed weight may have a negative impact (in the case of early harvesting or early desiccation) on seed yield, oil content and seed quality.

The correlation coefficient between characters assumes its importance due to genetic causes of correlation through pleiotropic actions of genes, linkage, improvement brought by selection through related characters and natural selection as concluded by Kaya et al. (2007) and Supriya et al. (2017). Supriya et al. (2017) also concluded that simultaneous improvement in two or more characters is possible when positive correlations are observed. 


\section{Path coefficient analysis}

The data were processed by path coefficient analysis which enabled the partitioning of direct and indirect effects of individual yield components and identification of yield components applicable as selection criteria in sunflower breeding.

\section{Seed Yield}

Relatively low coefficient of determination $\left(\mathrm{R}^{2}=0.515\right)$ gave rise to high residual effects (0.697) meaning that besides traits used in our study other causal variables may also be responsible for yield (Figure 1).

The study of direct effects on seed yield showed that the plant height had highly significant effect $(0.439 * *$; as confirmed by the high correlation coefficient $0.623^{* *}$ ). According to Sowmya et al. (2010), head diameter had the highest positive correlation and highest direct effect on seed yield while all other traits (plant height, dry mater, days of maturity, 100 seed weight) did not have any significant values. They also concluded that seed filling had high significant indirect effect (through head diameter) on seed yield. The highest positive direct effect on seed yield per plant was recorded by number of leaves, stem diameter, head diameter and 100 seed weight (Pandya et al., 2015). According to Jocković et al. (2015), the highest direct effect on seed yield was determined for head diameter and oil content, while for protein content and 1000-seed weight the effect was statistically significant. These authors also concluded that higher values of the direct effects of head diameter on seed yield than the values of correlation coefficients indicate that direct selection through this trait on seed yield improvement would be effective. Number of branches (high correlation coefficient $0.552^{* *}$ ) had positive direct effect, but not highly significant, on seed yield $\left(0.260^{*}\right)$. Marinković (1992) found significant direct effects of number of branches on seed yield, he also found negative effect of number of branches on head diameter. This author also concluded that this characteristic is only considerable for restorer lines, since sterile form does not have branches. We did not determine significant values in all other direct effects. Except effect of head diameter on yield, all other effects had negative values. Gorgieva et al. (2015) showed that 1000-seed weight has the highest direct positive effect on seed yield and they concluded that these results indicate that an increase of 1000 -seed weight causes some increase in sunflower seed yield. They also found that indirect positive effect on seed yield was obtained for oleic acid content and the highest negative indirect effect was determined for oil content. Kaya et al. (2008) determined direct effect of 1000-seed weight on seed yield and plant high. They also concluded that positive direct effect of important yield traits (such as 1000-seed weight, plant heigh and head diameter), based on their results, is main characteristics that exhibited the highest direct effect on seed yield, therefore these traits seem to be good selection criteria to improve sunflower hybrids seed yield. Kholghi et al. (2011) found that the 1000-seed weight had positive direct effect on yield of confectionary sunflowers. Chambo et al. (2017) determined non-significant direct effects of head diameter, seed germination and oil content on seed yield. According to Riaz et al. (2019) path analysis suggested head diameter is consistent selection criteria for increasing achene yield in sunflower. They also concluded that maximum positive direct effect of head diameter and high positive correlation with achene yield suggested that breeding on this trait can be useful for achene yield improvement in sunflower. The traits thousand achenes weight and number of achenes per head present direct effect on achenes yield based on agronomic performance and path analysis of sunflower grown in subtropical region at lower elevations. The head diameter does not present direct effect on achenes yield but it has direct effect on the number of achenes per head, indicating cause-effect relation and becoming an important alternative for indirect selection of sunflower cultivars (Follmann et al., 2019).

In the study of indirect effects, the existence of indirect significant effects on seed yield in thirteen cases was determined. Positive indirect effects were determined for number of leaves and head diameter: through plant heigh $\left(0.292^{*}\right.$ and $\left.0.308^{*}\right)$; through number of branches $\left(0.180^{*}\right.$ and $\left.0.060^{*}\right)$; through seed

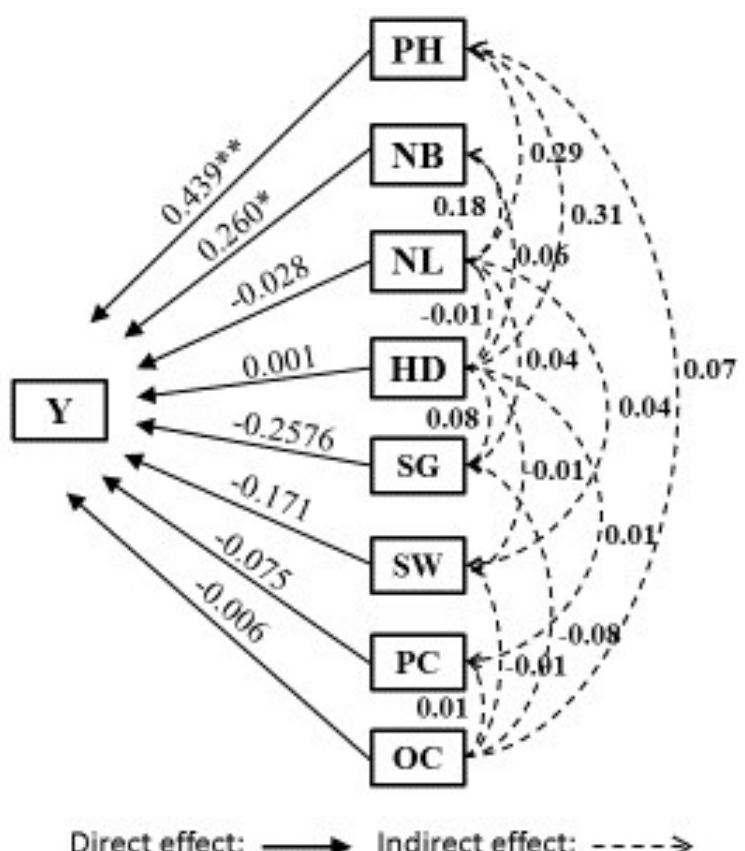

Figure 1. Analysis of direct and indirect effects of observed characters on seed yield in sunflower

PH - plant height; NB - number of branches; NL - number of leaves; HD - head diameter; SG = seed germination; SW - 1000 seed weight; $\mathrm{PC}$ - protein content; $\mathrm{OC}$ - oil content and $\mathrm{Y}$ - yield 
germination $\left(0.041^{*}\right.$ and $\left.0.083^{*}\right)$ and through 1000 -seed weight $\left(0.037^{*}\right.$ and -0.009$)$ on yield. All of these effects were positive except indirect effect of head diameter through 1000-seed weight on seed yield. Negative indirect effect was determined on head diameter ($\left.0.010^{*}\right)$ through number of leaves on seed yield. Positive indirect effect was determined on head diameter $\left(0.012^{*}\right)$ through protein content on seed yield (Figure 1). We also determined indirect effects of oil content: through plant high $\left(0.075^{*}\right)$; through protein content $(0.009 *)$; through seed germination $(-0.079 *)$ and 1000 seed weight $\left(-0.007^{*}\right)$ on seed yield. While first two effects were positive, last two had negative value. The results of this study are in agreement with results of Radić et al. (2013). While Farhatullah \& Khalil (2006) concluded that oil content had maximum direct effect on seed yield. In all other cases significant positive or negative values were not found.

\section{Oil Content}

Low coefficient of determination $\left(\mathrm{R}^{2}=0.440\right)$ gave rise to relatively high residual effects $(0.560)$ meaning that besides traits used in our study other causal variables may also be responsible for oil content (Figure 2).

The study of direct effects on oil content showed that the plant height and number of leaves diameter had high significant effects $\left(0.800^{* *}\right.$ and $-0.847^{* *}$; but it wasn't confirmed by the correlation coefficient 0.171 and -0.219). Difference between these two effects is that one of them is positive and other is negative. According

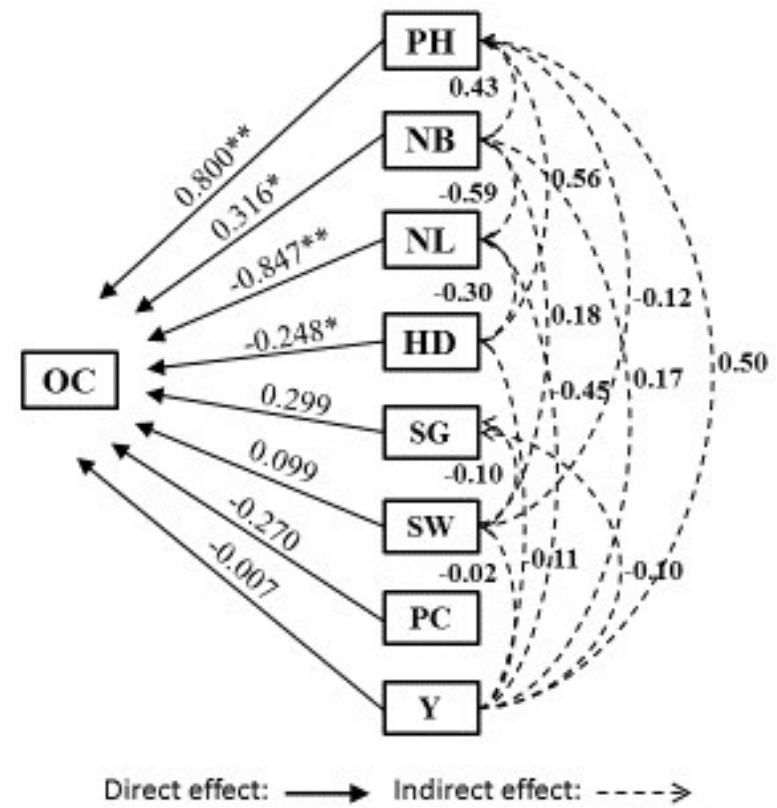

Figure 2. Analysis of direct and indirect effects of observed characters on oil content in sunflower

$\mathrm{PH}$ - plant height; NB - number of branches; NL - number of leaves; HD - head diameter; SG = seed germination; SW - 1000 seed weight; $\mathrm{PC}$ - protein content; $\mathrm{OC}$ - oil content and $\mathrm{Y}$ - yield to Supriya et al. (2017) plant height and head diameter had positive direct effects on oil content but these effects were not significant. For this author oil content showed highly significant positive correlation with test weight and with days to maturity at phenotypic level. They also recorded non-significant positive association with seed yield per plant. Chikkadevaiah \& Nandini (2002) concluded that direct effects on oil yield and oil content had yield per plant. Number of branches had positive direct effect, and head diameter (correlation coefficient -0.002 and 0.040 ) had negative direct effect. In both cases these effects were not highly significant on oil content $\left(0.316^{*}\right.$ and $\left.-0.248^{*}\right)$.

Significant values were not found in other direct effects. Effects of seed germination and 1000-seed weight had positive value while effects of protein content and seed yield had negative value on oil content. Results presented by Kaya \& Atakisi (2003) for plant height and mass of 1000 grain and Patil et al. (1996) for number of grains per head, 1000 grain weight and head weight reported highest direct effects on oil yield and oil content.

In the study of indirect effects, the existence of indirect significant effects on oil content in nine cases was determined (Figure 2). Chikkadevaiah \& Nandini (2002) concluded that maximum indirect effect for any character (plant height, head diameter, 1000-seed weight, number of leaves, day of flowering and oil yield) was through yield per plant which itself was a major contributor. Nehru \& Manjunath (2003) reported highest direct effect of seed yield and number of seed per head on oil content and further on oil yield per ha. This conclusion was confirmed by Mijić et al. (2009). It is determined positive indirect effects of number of branches, head diameter and seed yield through plant high $\left(0.431 * ; 0.561 *\right.$ and $\left.0.498^{*}\right)$ on oil content. Negative indirect effect was determined on number of branches, head diameter and seed yield $\left(-0.587^{*}\right.$ and $0.452 *)$ through number of leaves; 1000 -seed weight and seed yield $\left(-0.099^{*}\right.$ and $\left.-0.096^{*}\right)$ through seed germination and seed yield $\left(-0.016^{*}\right)$ through 1000 -seed weight on oil content. Significant positive or negative values were not found in other cases (Figure 2).

Breeding for oil yield along with high seed yield is the most important objective in any breeding programme of oil seed crops. These two parameters are always in positive correlation (Supriya et al., 2017). Oil content is very important parameter as breeding point of view. According to Tahir et al. (2019) achene oil content had positive direct effect (0.37) on achene yield per plant. Same authors concluded positive indirect effects on oil content were observed through leaf area and protein content; while plant height, internode length, leaves per plant, head diameter and 100 achene weight showed negative indirect effects; Tyagi (2011) and Chambo et al. (2017) also reported same results. 
Therefore, selection of this parameter would be effective to increase the achene yield per plant by improving the seed quality (Tahir et al., 2019).

\section{Conclusions}

A highly significant positive correlation was determined between plant height and number of branches; plant height and the number of leaves; plant height and head diameter; plant height and seed yield; number of branches and seed yield; the number of leaves and seed yield; head diameter and seed yield; number of leaves and number of branches; number of leaves and head diameter and between seed germination and oil content.

Plant height had the highest direct effect on seed yield, and number of branches had significant but not high direct effect. Plant height and number of leaves had the highest direct effects on oil content, while only direct effect of number of leaves had a negative value. Number of branches had significant but not high direct effect on oil content.

Based on our results and in order to improve the seed yield and oil content in sunflower genotypes it is better to select genotypes with high plant and branches and larger heads.

\section{References}

Anandhan T., Manivannan N., Vindhiyavarman P., Jeyakumar P (2010). Correlation for oil yield in sunflower (Helianthus annuus L.). Electronic Journal of Plant Breeding, 1 (4): 869-871.

Balalić, I., Zorić, M., Branković, G., Terzić, S., Crnobarac, J. (2012). Interpretation of hybrid $\times$ sowing date interaction for oil content and oil yield in sunflower. Field Crops Research, 137: 70-77.

Chambo E.D., Escocard de Oliveira N.T., Garcia R.C., RuvoloTakasusuki M.C.C., Arnaut de Toledo V.A. (2017). Phenotypic correlation and path analysis in sunflower genotypes and pollination influence on estimates. Open Biological Sciences Journal, 03: 9-15.

Chikkadevaiah SHL, Nandini R (2002). Correlation and path analysis in sunflower. Helia, 25(37): 109-118.

Darvishzadeh R., Hatami Maleki H., Sarrafi A. (2011). Path analysis of the relationship between yield and some related traits in diallel population of sunflower (Helianthus annuus L.) under well-watered and water-stressed conditions. Australian Journal of Crop Science, 5 (6): 674-680.

Farhratullah F.A., Khalil I.H. (2006). Path analysis of the coefficients of sunflower (Helianthus annuus L.) hybrids. Inter. J. of Agric. and Biol., 8(5): 621-625.

Follmann D.N., Filho A.C., dos Santos M.S., Costa V.O., Plautz E.N., Scopel J.V.F., Bamberg D.M., Engel G.H., Olivoto T., Wartha C.A., Nardino M. (2019). Correlations and Path Analysis in Sunflower Grown at Lower Elevations. Journal of Agricultural Science, 11(2), 455-453.

Gorgieva B., Karov I., Mitrev S., Ruzdik N.M., Kostadinovska E., Kovacevik B. (2015). Correlation and path analysis in sunflower (Helianthus annuus L.). Helia, 38(63): 201-210.

Hassan S.M.F., Iqbal1 M.S., Rabbani G., Naeem-ud-Din, Shabbir G., Riaz M., Noorka I.R. (2013). Correlation and path analysis for yield and yield components in sunflower (Helianthus annus. L). African Journal of Biotechnology, 12(16): 1968-1971.
Hladni N., Škorić D., Kraljević-Balalić M., Jocić S., Miklič V., Dušanić N. (2011). Line x tester analysis for yield components in sunflower and their correlations with seed yield (Helianthus annuus L.). Genetika, 43(2): 297-306.

Hladni N., Jocić S., Mijić A., Miklič V., Miladinović D. (2015). Correlation and path coefficient analysis for protein yield in confectionary sunflower (Helianthus annuus L.). Genetika, 47(3): 811-818.

Hladni N., Jocić S., Mijić A., Miklič V., Miladinović D. (2016). Correlation and path analysis of yield and yield components of confectionary sunflower. Genetike, 48(3): 827-835.

ISTA (International Seed Testing Association) (2014). ISTA Rules. Zurich. Switzerland.

Jalil S., Sadaqat H.A., Tahir H.N. (2014). Correlation studies among yield related traits for seed yield in sunflower (Helianthus annuus L.) under charcoal rot stress conditions. European Scientific Journal, 10(9): 391-398.

Jocković M., Jocić S., Marjanović-Jeromela A., Ćirić M., Čanak P., Miklič V., Cvejić S. (2015). Biomorphological association and path Analysis in sunflower (Helianthus annuus L.). Helia, 38: 189-199.

Kaya Y., Atakisi I.K. (2003). Path and correlation analysis in different yield characters in sunflower (Helianthus annuus L.). Anadolu Journal, 13: 31-45.

Kaya Y., Evci G., Durak S., Pekcan V., Gucer T., (2007). Determining the relationships between yield and yield attributes in sunflower. Turkish Journal of Agriculture and Forestry, 31: 237-244.

Kaya Y., Evci G., Pekcan V., Gucer T., Durak S., Yilmaz M.I. (2008). The path analysis of yield traits in sunflower (Helianthus annuus L.). Agronomijas Vèstis (Latvian J. of Agron.), 11: 72- 6.

Kholghi M., Bernousi I., Darvishzadeh R., Pirzad A., Hatami Maleki H. (2011). Collection, evaluation and classification of Iranian confectionary sunflower (Helianthus annuus L.) populations using multivariate statistical techniques. African Journal of Biotechnology, 10: 5444-5451.

Manivannan N., Karthika R., Punitha B., Vindhiyavarman P., Muralidharan V. (2008). Association pattern among the yield attributes in varieties and hybrids of sunflower (Helianthus annuus L.). Helia, 31(49): 83-90.

Marinković R. (1992). Path-coefficient analysis of some yield components of sunflower (Helianthus annuus L.). Euphytica, 60: 201205.

Mijić A., Liović I., Zdunić Z., Marić S., Marjanović-Jeromela A., Jankulovska M. (2009). Quantitative analysis of oil yield and its components in sunflower (Helianthus annuus L.). Romanian Agricultural Research 41-46.

Miklič V., Mrđa J., Modi R., Jocić J., Dušanić N., Hladni N., Miladinović D. (2012). Effect of location and harvesting date on yield and 1,000-seed weight of different sunflower genotypes. Romanian Agricultural Research, 29: 219-225.

Mrđa J., Crnobarac J., Dušanić N., Jocić S., Miklič V. (2011). Germination energy as a parameter of seed quality in different sunflower genotypes. Genetika, 43(3): 427-436.

Nehru, S.D., Manjunath, A., 2003. Correlation and path analysis in sunflower (Helianthus annuus L.). Karnataka Journal of Agricultural Science, 16(1): 39-43.

Patil B.R., Rudraradhya M., Vijayakumar C.H.M., Basappa H., Kulkarni R.S. (1996). Correlation and path analysis in sunflower. Journal of Oilgrains Research, 13(2): 162-166.

Pandya M.M., Patel P.B., Narwade A.V. (2015). A study on correlation and path analysis for seed yield and yield components in sunflower (Helianthus annuus L.). Electronic Journal of Plant Breeding, 6(2): 540-545.

Pekcan V., Evci G., Yilmaz I., Kaya Y. (2015). Developing confectionery sunflower hybrids and determination of their yield performances in different environmental conditions. Ekin Journal of Crop Breeding and Genetics, 1-2: 47-55.

Radić V. (2008). Productive and morphological characteristics of Novi Sad commercial sunflower (Helianthus annuus L.) lines. $\mathrm{PhD}$ thesis, Faculty of Agriculture, University of Novi Sad, Novi Sad, Serbia, 80. 
Radić V., Mrđa J., Terzić S., Dedić B., Dimitrijević A., Balalić I, Miladinović D., (2013). Correlations and path analyses of yield and other sunflower seed characters. Genetika, 45: 459-466.

Riaz A., Tahir M.H.N., Rizwan M., Fiaz S., Chachar S., Razzaq K., Riaz B., Sadia H. (2019). Developing a Selection Criterion Using Correlation and Path Coefficient Analysis in Sunflower (Helianthus annuи L.). Helia, 42(70): 85-90.

Shankar V.G., Ganesh M., Ranganatha A.R.G., Bhave M.H.V. (2006). A study on correlation and path analysis of seed yield and yield components in sunflower (Helianthus annuus L.). Agricultural Science Digest, 26(2): 87-90.

Sincik M., Goksoy A.T. (2014). Investigation of correlation between traits and path analysis of confectionary sunflower genotypes. Notulae Botanicae Horti Agrobotanici, 42(1): 227-231.

Singh V.K., Sheoran R.K., Chander S. (2018). Correlation analysis for seed yield and its component traits in sunflower. Journal of Pharmacognosy and Phytochemistry, 7(3): 2299-2301.

Supriya S.M., Kulkarni V.V., Ranganatha C.N., Suresha P.G. (2017). Quantitative Analysis of Oil Yield and Its Components in newly developed hybrids of sunflower (Helianthus annuus L.). International Journal of Current Microbiology and Applied Sciences, 6(8): 3088-3098.

Sowmya H.C., Shadakshari Y.G., Pranesh K.J., Srivastava A., Nandini B. (2010). Character association and path analyses in sunflower (Helianthus annuus L.). Electronic Journal of Plant Breeding, 1(4): 828-831. StatSoft (2009). STATISTICA 12.0. StatSoft Inc.

Tahir A., Iqbal M.A., Saif R., Qadir M., Sultana R. (2019). Correlation and Path Coefficient Analysis for Morphological and Biochemical Parameters in Sunflower (Helianthus annuиs L.). Helia, 42 (70), https://doi.org/10.1515/helia-2018-0011: 61-72.

Tyagi S.D. (2011). An analysis of the association factors influencing seed yield and oil percentage in sunflower (Helianthus annuus L.). Journal of Progressive Agriculture 11(1): 149-155.

Yankov B., Tahsin N. (2015). Genetic variability and correlation studies in some drought-resistant sunflower (Helianthus annus L.) genotypes. Journal of Central European Agriculture, 16(2):212-220.

Yasin A.B., Singh S. (2010). Correlation and path coefficient analyses in sunflower. Journal of Plant Breeding and Crop Science, 2(5): 129-133.

\section{Analiza korelacije i path koeficijenta pojedinih parametara roditeljskih linija suncokreta}

\section{Velimir Radić · Igor Balalić · Goran Jaćimović · Miloš Krstić · Milan Jocković · Siniša Jocić}

Sažetak: Ispitivani su odnosi prinosa semena i osam svojstava kod suncokreta - sadržaj ulja i proteina u semenu, klijavost semena, težina 1000 semena, prečnik glave, broj grana, broj listova i visina biljke. Ista analiza urađena je za sadržaj ulja u semenu suncokreta. Statistički visoko značajna korelacija utvrđena je upoređivanjem sledećih parametara ispitivanja: visina biljke i broja bočnih grana; visina biljke i prinosa semena; broja bočnih grana i prinosa semena; broja listova i prinosa semena; prečnika glave i prinosa semena; broja listova i broja bočnih grana; broja listova i prečnika glave te klijavosti semena i sadržaja ulja u semenu. Path analiza je pokazala visoko statistički značajan pozitivan direktan uticaj visine biljke na prinos semena $(0,439 * *)$ suncokreta. Broj grana po biljci imao je statistički značajan pozitivan direktan uticaj na prinos semena $\left(0,260^{*}\right)$. U posmatranju indirektnih efekata na prinos utvrđeno je trinaest različitih statistički značajnih slučajeva. Kod analize direktnih efekata na sadržaj ulja u semenu utvrđeni su visoko statistički značajne vrednosti kod visine biljke i broja listova $\left(0,800^{* *}\right.$ i $\left.-0,847^{* *}\right)$. Prilikom analize indirektnih efekata na sadržaj ulja u semenu suncokreta utvrđeno je devet statistički značajnih slučajeva.

Ključne reči: suncokret, korelacija, path analiza, komponente prinosa

This article is distributed under the terms of the Creative Commons Attribution 4.0 International License (http://creativecommons.org/licenses/by/4.0) which permits unrestricted use, distribution and reproduction in any medium, provided you give appropriate credit to the original author(s) and the source, provide a link to the Creative Commons license, and indicate if changes were made. 